\title{
SMART VILLAGES AND RURAL DEVELOPMENT
}

\author{
Zoran Jezic $^{1 \times}$, Aleksandra Górecka ${ }^{2}$, Benjamin Kardum ${ }^{1}$ \\ ${ }^{1}$ University of Rijeka, Croatia \\ ${ }^{2}$ Warsaw University of Life Sciences - SGGW, Poland
}

\begin{abstract}
The "smart village" concept is relatively new among EU decision- and policy-makers; it is a result of many years of debate, economic and territorial inequalities, social exclusion, diversification of certain areas, gradual reduction of agricultural activities and the interaction of cohesion, regional, and common agricultural policy. The concept of smart villages implies saving villages and their inhabitants, protecting cultural heritage and using local potentials to meet modern challenges. In its initial stages, it requires activities of all stakeholders, from individuals living in the rural area in question to decision-makers participating in identifying the strengths, threats, opportunities, and weaknesses of a certain rural area. Apart from the theoretical definition of smart villages, this paper aims to analyse European regulations of smart villages, and to define the challenges and smart village traps in rural development and ways in which they can be prevented.
\end{abstract}

Key words: rural development, smart villages, rural development trap, economic growth and development

JEL codes: O1, O13, P25

\section{THEORETICAL APPROACH TO RURAL DEVELOPMENT}

Rural areas play a key role in addressing 21 st century opportunities and challenges; natural resources found in rural areas can provide new forms of energy in response to climate challenges, and agricultural innovation can help address the challenge of growing food demand. However, structural changes and industries based on the wanton exploitation of natural resources, combined with a decrease on rural populations, hampers the development of rural areas, leading to dissatisfaction and reduced quality of life. Governmental capacity to effectively deal with the challenges and opportunities facing rural areas plays an enormous role in addressing these issues, and can affect future cohesion and prosperity [OECD 2019].
The natural resources that people rely on are disappearing, and their importance and usage is changing. Institutions have become less stable, there are constant changes in market processes, and globalisation is redefining the meaning of 'territory', 'local space', and 'distance'. Many uncertainties need to be addressed in order to solve problems in rural development, and considerations regarding the active role of civil society have become key issues in fighting negative impacts and redefining rural development parameters [FAO 2005]. Territorial vision, establishing a common identity and supporting the implementation of development plans are achieved by adapting instruments, activities, projects, and strategies. To do this, local rural populations need to participate. 
Agricultural and rural economies are seeing a growing decrease in relation to industrial, service, and urban economies. On the other hand, rural areas are increasingly characterised by marginal agricultural activities and households that do not possess arable land. In certain surveys, this is described as the dominant agricultural phenomenon of the present day and referred to as 'depeasantisation', which, loosely translated, means pushing out farming (formerly known as 'peasant') activity [Maxwell et al. 2001].

These facts, underlying the changing nature of agriculture and rural communities, demonstrate that it is not sufficient to merely point out the different structures of rural areas, but rather to show that these areas have varied limitations, and thus require the implementation of different strategies for their development. Considering the experiences, challenges, and need for greater convergence of rural areas, the European Union is focused on developing and implementing the "smart village" concept. This concept aims to include all the inhabitants, public authorities, associations, interest groups, entrepreneurs, and investors who can help in demographic and economic revitalisation, as well as further development, of rural areas. The aim of this paper, based on a literature review, is to explain the connection between the development of smart villages and general economic development. Emphasis will be placed on the challenges in developing smart villages, explanation of the rural development trap, and proposals on how to avoid it.

\section{HISTORICAL REVIEW OF THE EUROPEAN REGULATORY FRAMEWORK ON SMART VILLAGES WITH A LITERATURE REVIEW}

The first European Conference on Rural Development, entitled "A Living Countryside", was held in Cork, Ireland on November 7th-9th, 1996. The conference highlighted the importance of rural areas and their population as drivers and representatives of the real advantage of the European Union, and as factors generating market potential and competitiveness. It also called for increased efforts in promoting local capacity building for sustainable development in rural areas, with particular emphasis on financial incentives aimed at developing private initiatives.
Conference participants supported the view that public financial incentives for rural development aimed at conserving biodiversity, as well as proper and responsible management of natural resources and financial planning, was becoming more significant and acceptable. The conference resulted in the adoption of The Cork Declaration, with ten key guidelines in the form of elaborated subparagraphs: rural preference, integrated approach, diversification, sustainability, subsidiarity, simplification, programming, finance, management, evaluation and research [European Commission 1996]. The conclusions and lessons of the conference and the Declaration helped the European Commission to define the guidelines and recommendations related to the Structural Funds for the period 2000-2006, and they addressed in detail the issues of improving integration between cities and rural areas, sustainability of European agriculture, the aspect of improved competitiveness and achieving better sustainable development in rural areas.

Twenty years after the first Cork Declaration, the second European Conference on Rural Development, entitled "A Better Life in Rural Areas", was held on September 5th and 6th, 2016. It resulted in Declaration 2.0, which was oriented towards a better quality of life in rural areas. The Declaration reached the conclusion that an inclusive rural and agricultural policy should be based on an innovative, inventive, smart, and integrated approach, under the following guidelines: promoting rural prosperity, strengthening rural value chains, investing in rural viability and vitality, preserving the rural environment, managing natural resources, encouraging climate action, boosting knowledge and innovation, Enhancing Rural governance, advancing policy delivery and simplification, and improving performance and accountability [European Commission 2018].

Thanks to the Cork 2.0 Declaration, access to technological and scientific solutions reached a higher level; it was pointed out that such solutions are the basis for economic growth, development and sustainability, provided that these solutions are based on an interactive approach. This approach should use the "bottom-up" principle which ultimately facilitates the accessibility of solutions to all rural inhabitants, farmers, fishermen, entrepreneurs, foresters, 
and all other stakeholders. This consequently leads to efficient use of limited resources, development of circular economies, reduction or complete elimination of dependence on non-renewable energy sources, achieving quality food supply, and facilitation of the fight against climate change. One of the particularly important topics was the problem that many rural areas in the European Union level are facing: emigration of the population, especially young people gravitating to more urban regions, leaving rural areas uninhabited. The greatest progress in comparison with the previous declaration is a greater focus on developing an integrated, more coherent and more complementary approach between different policies. Cork 2.0 is considered a milestone in popularising awareness aimed at empowering rural areas and providing people with a bigger picture in understanding that sustainable urban development greatly depends on prosperity and investment in rural areas. [Atkočiünienë and Vaznonienë 2019].

Two years later, on April 13th, 2018, under the initiative of Members of the European Parliament, a conference was held in Bled, Slovenia and, in conclusion, the Bled Declaration entitled "Smarter Future of the Rural Areas in the EU" was signed. The Declaration took into account all the previous conclusions of the Cork declarations and called for further actions to digitise rural areas. This led to the development of a concept called "smart villages" and complemented the vision of rural development with new strategic objectives and guidelines based on the usage of digital and smart solutions. Such solutions aim to combat migration and the outflow of population from rural areas, as well as provide equal opportunities in terms of education, infrastructure, health, employment, services, energy, transport, and general quality of life for all rural inhabitants, equal to that of inhabitants of urban areas [Mašić 2019]. The signatories of the Bled Declaration expressed their belief that the concept of "smart villages" can fight social exclusion and rural poverty by creating jobs in agriculture and that simplifying access to the funding range can lead to synergic effects in encouraging investment. It became clear that the "smart village" concept is an appropriate tool that will help maintain, restore, and develop rural communities and promote social and digital transformation that is crucial for the future of agriculture and food throughout the European Union.

Since the emergence of the concept of smart villages, several authors have distinguished themselves in the analysis of the impact of smart village development on economic growth and development: Somwanshi et al. [2016], Vaishar and Št’astná [2019]. Adamowicz and Zwolińska-Ligaj [2020] analyse how smart villages can contribute as a way to achieve sustainable development in rural areas of Poland. Also, there is large importance of the role of local government units in animating rural development which is being analyzed by different authors: Satola [2015], Milewska and Jóźwik [2014] and Rutuja [2016]. It must be emphasized that economic growth and development is not possible without financial possibilities of the local administrations: Satola [2015], Kozera, Standar and Satoła [2020] and Standar, Kozera and Satoła [2021].

\section{THE IMPORTANCE OF THE SMART VILLAGE CONCEPT FOR RURAL DEVELOPMENT}

The principle of territorial rooting is considered the most useful in defining smart villages and relates to the use of local resources to achieve optimal development of the target area in the economic and social sense. Rooting implies the idea of adopting a sustainability strategy that does not destroy the available economic and social resources of a certain natural area, but rather enables its further development in the future. The implementation of rooting results in a specific socioeconomic system of interdependence which, along with adequate and responsible resource management, maximises their benefits in a certain area and creates prosperity for the local community and development [Guzal-Dec 2018].

The "smart village" concept is relatively new among European Union decision- and policy-makers as a result of many years of debate, economic and territorial inequalities, social exclusion, diversification of certain areas, gradual reduction of agricultural activities and interaction of the cohesion, regional, and common agricultural policy. "Smart villages" are primarily about people from villages who are taking the initiative to find practical solutions for local disadvantages, but also opportunities. Finding a solution implies using 
all available tools and instruments, and digital technologies are only one of the possible tools to achieve a smart approach in development. The implementation of the "smart village" concept dictates acting outside of local frameworks, which means establishing good and quality partnerships with other villages, small and large cities, as well as the development of good relations with entrepreneurs. It includes business models such as the circular economy, social innovation, the sharing economy, the bioeconomy, etc., which are based on development policies aimed at using scientific achievements and new information and communication technologies. [Visvizi et al. 2019].

In 2017, the European Committee of the Regions communicated an opinion on the topic "Revitalising Rural Areas Through Smart Villages". The opinion called for greater ambition of European decision-makers with a view to the post-2020 period regarding rural development. It suggested extending the concept of "smart villages" to a concept of "smart rural areas", and incorporating the initiative into the European Rural Agenda in order to develop and foster a synergy between small local units within rural areas. Since the "smart village" concept is unique for each area in which it is implemented, the Committee of the Regions noted that the development of smart areas must be based on their own social and cultural values, as a way to show their specific local identities, which can be one of the means to attracting small and mediumsized enterprises from urban areas [Committee of the Regions 2017].

According to Visvizi et al. [2019], conceptual frameworks of "smart villages" are defined by the following statements and assumptions: a village represents an ecosystem of a limited size as well as a community driven by specific mechanisms and dynamics that are a product and result of interaction between a large number of stakeholders; a "smart village" is conceptually different from a group concept of a "rural area" or "rural region", as a village is conceptually and empirically different from a "smart city"; the issue and corresponding research on 'value added' of information, communication and technologies in the context of villages has unique characteristics that differentiate it from research on "smart cities"; the emphasis in research on "smart villages" is refocused on the inhabi- tants of a certain village, regardless of whether they are a group or individuals; the concept of a village is considered ontologically different from the concept of a city, and leads to research on "smart villages" that is separate from research on "smart cities"; separate research on "smart villages" uses the insights from debates on ICT to deal with the problems, challenges, and opportunities faced by the villages and their inhabitants in the 21 st century in a conceptually proper, empirically focused and ethically conscious manner.

The Committee of the Regions believes that the "smart village", i.e. the "smart rural area" initiative should be modelled on the "smart cities" model, which would include a broad approach to development and innovation based on six different dimensions [Committee of the Regions 2017]: smart, innovative, entrepreneurial and productive economy; improved mobility with accessible, modern and sustainable transport networks; environment and sustainable energy vision; qualified and engaged citizens; quality of life in terms of culture, health, security, and education; efficient, transparent, and ambitious government (administration). These arguments indicate that "smart villages" have been gaining distinction and a form of perception regarding "ordinary" rural areas, as well as urban areas that can be managed by a special concept of "smart cities". This leads to the conclusion that "smart villages" are perceived as a developmental approach bringing a different development philosophy which has a multiplicative effect in creating 'value added' in rural areas and achieving greater socio-economic and environmental sustainability.

\section{CHALLENGES OF SMART VILLAGES AND THE "RURAL DEVELOPMENT TRAP"}

Rural areas are universally accepted as areas located outside the borders of large and medium urban areas, which implies limited choices in management and infrastructure capacities. In most cases, the greater the distance from urban areas, the greater the diversity in socio-economic structures and exposure to the various problems rural areas are facing. Certain problems also attract other problems that are reflected as a "domino effect". This makes certain rural areas fall into a rural development trap which prevents the realisation of full 
development potential, which can lead to stagnation, displacement, or abandonment of certain rural areas. In Figure is a schematic overview of the rural development trap.

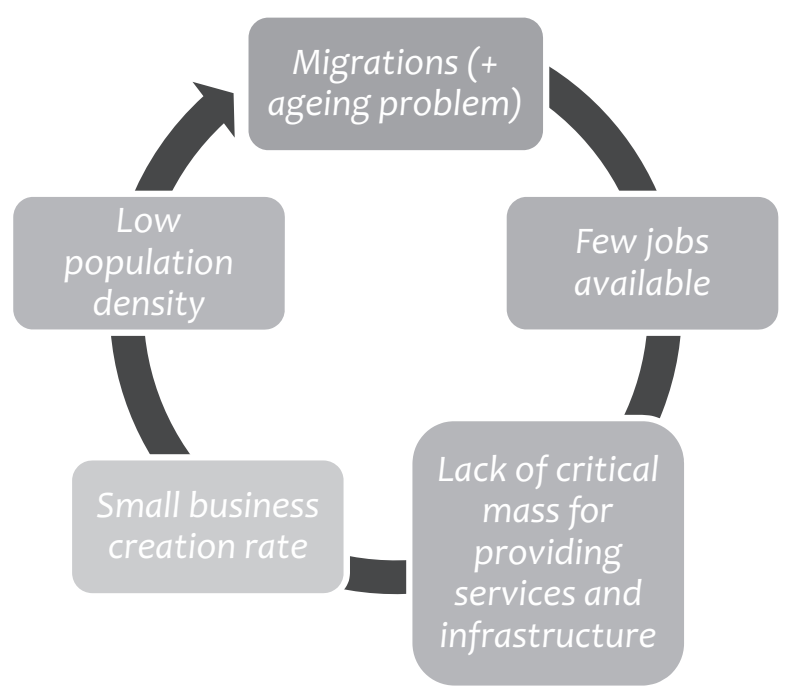

Fig. Rural Development Trap

Source: Authors' processing according to [ENRD 2018].

Rural underdevelopment is usually caused by various challenges that together constitute a rural (non)development trap. The trap may include several challenges, including: climate change, low population density, limited access to health services, limited market access, no co-operation with other villages or cities, migration effects (outflow of young people to more urban areas), non-existent or insufficient school system facilities, share of ageing population, fragmentation of rural communities, lack of access to high-speed broadband Internet, limited social infrastructure, insufficient provision of basic services, underdeveloped or non-existent transport infrastructure, insufficient concentration of entrepreneurial activities, lack of available jobs, lack of funding by local government units, etc. It should be noted that these are only some of the potential challenges and barriers to the development of rural areas and are highly dependent on factors such as administrative capacity level, management quality, geographical, social, and economic characteristics.

According to European Network for Rural Development [ENRD 2018], the five most commonly iden- tified challenges constituting a (non)-development trap, which need to be addressed under the concept of „smart villages" in order to revitalise rural areas, are the following:

1. Reaction to depopulation, migration of young people and dominance of the elderly population (demographic changes);

2. Finding solutions for local action, i.e. decentralisation and increasing public funding;

3. Exploiting the connection with cities in every sense;

4. Maximising the role of rural areas in the transition to low-carbon circular economies;

5. Promoting digital transformation of rural areas.

As the first challenge, depopulation is often considered one of the consequences of rural underdevelopment, but viewed from another angle, depopulation can be seen as one of the causes leading to gradual stagnation or regression of rural areas. One of the most important issues in rural areas is the prevention of the exodus of young people to urban areas since many young people gravitate to places (most often urban) that provide better employment opportunities, and in turn offer a better quality of life. Depopulation of rural areas additionally aggravates the economic status of rural communities and simultaneously increases the pressure on urban areas [Council of Europe 2018].

The second challenge is that the negative consequences of centralisation in small rural areas are most noticeable from the financial perspective since in most cases local government units primarily allocate funds to more developed areas for their further growth and development, as well as for attracting more inhabitants, while, on the other hand, small places remain at a disadvantage. Also, the centralised decision-making system leads to solutions that are sometimes not the most suitable for all areas covered by local and regional self-government. Taking into account these arguments, in the long run, this approach leads to increasing inequalities between different rural and urban areas, exposing a certain part of the population to an (unnecessary) increased risk of poverty.

In the past, rural areas mostly depended on urban areas, and nowadays, these two areas have become more interdependent. The third identified challenge can be explained by the fact that villages cannot function without cities, and cities cannot function without 
villages. The focus in this context may be on transport infrastructure connectivity that facilitates daily migrations of inhabitants using elaborate roads and railways to carry out private, business, and educational activities. One of these steps is the realisation of intellectual connectivity, and to achieve intellectual connectivity at the national level, efforts should be made to develop mechanisms and policies that would support rural-urban connections. Such an approach leads to the creation of intellectual clusters and accumulation of knowledge, and the role of clusters would be the concentration of educated population, experts, scientists, specialised agencies and various institutions that would generate knowledge, inventiveness, and innovation.

The fourth challenge refers to maximising the role of rural areas in the transition to low-carbon circular economies. New rural value chains such as the circular economy, clean energy generation, the new bioeconomy and eco-tourism are key factors in developing a low-carbon economy, creating job opportunities and enabling quality growth and development. A circular economy consequently leads to fostering a smart and resilient agricultural economy, strengthening the socio-economic structure of rural areas, improving environmental protection and contributing to the European Union's climate and environmental objectives.

Digital technologies have been accepted by a large share of the population and have had a significant transformative effect on daily lives. There are certain divisions and differences in societies when it comes to broadband network access between rural and urban areas, and these differences may be branched on age and gender characteristics. This creates the need to reduce the gap to ensure an inclusive digital transformation and make full use of the opportunities and possibilities provided [OECD 2019]. Digital innovation requires access to digital networks, skills in using the networks, capability and willingness of individuals and communities to seek changes and develop solutions to address environmental, social, and economic challenges. Increased accessibility to a high-speed broadband network in more rural communities has set the stage for rural stakeholders to play an important role in the development of the digital society and economy. True digital "bottom-up" transformation in rural, peripheral, and growing regions is much more than acceleration of digital technology usage; it is the insurance that every rural village, small city, and region, as well as their communities, can translate the potential of digital technologies into economic and social possibilities. Digital transformation in rural areas generates the greatest 'value added' in the agriculture sector. The presence, portability and mobility of digital technologies open many opportunities for farmers to facilitate food production, increase production, reduce operating costs, increase productivity, and simplify the supply chain.

\section{CONCLUSIONS}

The "smart village" concept is relatively new among European Union decision- and policy-makers; it is a result of many years of debate. On the other hand, structural changes and industries based on the exploitation of natural resources, combined with the loss of population hamper the development of rural areas, which leads to economic regression and reduced quality of life for the population. Rural areas are increasingly characterised by marginal agricultural activities and households that do not possess arable land. These facts lead to the conclusion that it is not sufficient to merely point out that there are different structures of rural areas, but that these areas have certain limitations. This also requires the implementation of different strategies for their development.

Since 1996, the European Union has formed a legal framework for the development of rural areas at various conferences, with particular emphasis on smart villages. "Smart villages" are primarily focused on people from villages who are taking the initiative to find practical solutions for local disadvantages, but also opportunities. Finding a solution implies using all available tools and instruments, and digital technologies are only one of the possible tools to achieve a smart approach to development. However, there are also five important challenges in the development of smart villages: depopulation, migration of the young population, finding solutions for local action, exploiting connections with cities in every sense, switching to low-carbon circular economies and promoting digital transformation of rural areas. 
Having set up a theoretical framework of smart villages and rural development, in the papers to follow, the authors plan to develop a model and measure the components of the development of smart villages for the Republic of Croatia and selected European Union countries.

\section{ACKNOWLEDGEMENTS}

This paper was founded under the project line ZIP UNIRI of the University of Rijeka, for the project ZIPUNIRI-130-9-20 (E-)education and Human resources Development

\section{REFERENCES}

Adamowicz, M., Zwolińska-Ligaj M. (2020). The "Smart Village" as a Way to Achieve Sustainable Development in Rural Areas of Poland. Sustainability 12(16), 6503.

Atkočiünienë, V., Vaznonienë, G. (2019). Smart Village Development Principles and Driving Forces: The Case of Lithuania. European Countryside 11(4), 497-516. Retrieved from https://content.sciendo.com/view/journals/euco/11/4/article-p497.xml?language=en [accessed: 13.03.2020].

Committee of the Regions (2017). Revitalisation of rural areas through Smart Villages. Retrieved from https:// cor.europa.eu/en/our-work/Pages/OpinionTimeline. aspx?opId=CDR-3465-2017 [accessed 08.05.2021].

Council of Europe (2018). Young people in rural areas - contemporary issues in youth policy. Retrieved from https://pjp-eu.coe.int/en/web/youth-partnership/youngpeople-in-rural-areas [accessed 22.03.2020].

ENRD (2018). EU Rural Review 26 "Smart Villages: Revitalising Rural Services". Retrieved from https:// enrd.ec.europa.eu/publications/eu-rural-review-26smart-villages-revitalising-rural-services_en [accessed 07.03.2020].

European Commission (1996). Rural development conference - Cork declaration: living countryside. Retrieved from https:/ec.europa.eu/commission/presscorner/detail/en/IP_96_1007 [accessed 20.03.2020].

European Commission (2018). Smart Village: Bled Declaration for a Smarter Future of the Rural Areas in EU. Retrieved from https://ec.europa.eu/info/news/europe an-commission-supports-call-smarter-future-rural-areas-2018-apr-13_en [accessed 13.03.2021].

FAO (2005). An approach to rural development: Participatory and Negotiated Trritorial Development (PNTD). Retrieved from http://www.fao.org/3/a-ak228e.pdf [accessed 30.04.2021].

Guzal-Dec, D. (2018). Intelligent Development of the Countryside - The Concept of Smart Villages: Assumptions, Possibilities, and Implementation Limitations. Economic and Regional Studies 11, 3, 32-49, https:// doi.org/10.2478/ers-2018-0023

Kozera, A., Standar, A., Satoła, Ł. (2020). Managing Rural Areas in the Context of the Growing Debt of Polish Local Government Units. Agriculture 10(9), 376, https:// doi.org/10.3390/agriculture10090376

Mašić, M. (2019). Mogu li "Pametna sela" spasiti pusta sela Hrvatske? Agroklub(r) Evolucija poljoprivrede. Retrived from https://www.agroklub.com/kolumna/moguli-pametna-sela-spasiti-pusta-sela-hrvatske/51624/ [accessed 25.03.2021].

Maxwell, S., Urey, I., Ashley, C. (2001). Emerging Issues in Rural Development Overseas. Overseases Development Institute, London. Retrieved from https://www.odi.org/ sites/odi.org.uk/files/odi-assets/publications-opinionfiles/5898.pdf [accessed 15.04.2021].

Milewska, A., Jóźwik, M. (2014). Organization and changes of local government finance system in view of implementation of participatory budgeting. Acta Scientiarum Polonorum. Oeconomia 13(4), 125-134.

OECD (2019). Regional Outlook 2019 Leveraging Megatrends for Cities and Rural Areas. Retrieved from https:// www.oecd.org/regional/oecd-regional-outlook-20199789264312838-en.htm [accessed 15.04.2021].

Somwanshi, R., Shindepatil, U., Tule, D., Mankar, A., Ingle, N. (2016). Study and development of village as a smart village. International Journal of Scientific \& Engineering Research 7(6), 395-408.

Satola, Ł. (2015). Debt of Communes in the Light of a New Individual Debt Ratio. Acta Scientiarum Polonorum. Oeconomia 14(4), 103-113. Retrieved from https://aspe. sggw.pl//article/view/4202/3728 [accessed 25.08.2021].

Standar, A., Kozera, A., Satoła, Ł. (2021). The Importance of Local Investments Co-Financed by the European Union in the Field of Renewable Energy Sources in Rural Areas of Poland. Energies 14(2), 450, https://doi. org/10.3390/en14020450 
Vaishar, A., Št’astná, M. (2019). Smart Village and Sustainability. Southern Moravia Case Study. European Countryside 11(4), 651-660.

Visvizi, A., Lytras, M., Mudri, G., (2019). Smart Village in the EU and beyond. School of Business, Deree College-
The American College of Greece. European Parliament, Bruxelles. Retrieved from https://pdfs.semanticscholar. org/fd6c/b2ace34f9c33c0f0ba0fa9d050b063e53c4a. pdf?_ga=2.240876867.1335396507.1587896620891313435.1587896620 [accessed 17.03.2021].

\section{INTELIGENTNE WSIE A ROZWÓJ OBSZARÓW WIEJSKICH}

\section{STRESZCZENIE}

Koncepcja „smart village” tj. inteligentnych wsi jest stosunkowo nowa w kontekście polityki oraz podejmowanych decyzji w Unii Europejskiej. Jest wynikiem wieloletnich debat dotyczących nierówności gospodarczych i terytorialnych, wykluczenia społecznego, dywersyfikacji obszarów, stopniowego ograniczania działalności rolniczej oraz współdziałania polityki spójności, regionalnej i wspólnej polityki rolnej. Koncepcja inteligentnych wsi zakłada pomoc obszarom wiejskim, ich mieszkańcom, ochronę dziedzictwa kulturowego i wykorzystanie lokalnego potencjału w celu sprostania współczesnym wyzwaniom. W początkowej fazie jej implementacji wymaga działania wszystkich interesariuszy, poczynając od osób mieszkających na danym obszarze po decydentów uczestniczących w identyfikacji mocnych stron, zagrożeń, szans i słabych stron terenu. Celem artykułu było wskazanie istoty i koncepcji smart villages, ocena europejskich przepisów dotyczących inteligentnych wsi oraz wskazanie wyzwań i problemów, jakie niesie wdrożenie koncepcji w rozwoju obszarów.

Słowa kluczowe: rozwój obszarów wiejskich, inteligentne wsie, pułapka rozwoju obszarów wiejskich, wzrost gospodarczy, rozwój gospodarczy 